\title{
8
}

Research Square

\section{Investigating Teachers' Self-efficacy, Instructional Practice and Self-reflective Practice: The Case of Tertiary Level Teachers}

Shabnam Kurosh Khanshan ( $\nabla$ shabnamkorosh@gmail.com )

English Language Department, Urmia Branch, Islamic Azad University, Urmia, Iran Mohammad Hossein Yousefi

English Language Department, Bonab Branch, Islamic Azad University, Bonab, Iran

Seyyed Hossein Kashef

English Language Department, Urmia Branch, Islamic Azad University, Urmia, Iran

Original article

Keywords: self-efficacy, instructional practice, reflective practice, tertiary education

Posted Date: August 13th, 2020

DOI: https://doi.org/10.21203/rs.3.rs-56302/v1

License: (1) This work is licensed under a Creative Commons Attribution 4.0 International License.

Read Full License 
Investigating Teachers' Self-Efficacy, Instructional Practice and Self-Reflective Practice:

\title{
The case of Tertiary Level Teachers
}

\author{
${ }^{1}$ Shabnam Kurosh ( shabnamkorosh@gmail.com) \\ ${ }^{2}$ Mohammad Hossein Yousefi ( mhh.yousefi@gmail.com) \\ English Language Department, Bonab Branch, Islamic Azad University, Bonab, Iran \\ ${ }^{3}$ Seyyed Hossein Kashef (mhkashef@gmail.com) \\ ${ }^{1 \& 3}$ English Language Department, Urmia Branch, Islamic Azad University, Urmia, Iran
}




\begin{abstract}
The present study was an attempt to shed light on university level teachers' self-efficacy perceptions in relation to their reflective practice and instructional practice. For this purpose, 70 teachers from both public and private universities in Iran took part in this survey research. Participants were asked to fill out three Likert-type questionnaires: Teacher Efficacy Scale, The Instructional Practices Survey, and Teacher Reflection Questionnaire. The collected data were quantitatively analyzed using SPSS version 21. The results of Pearson correlation coefficients revealed that although teachers' self-efficacy perceptions were significantly correlated with both their instructional practice and reflective practice, the former established a relationship with a higher effect size than the latter. Implications of the results with respect to teacher development are presented and directions for further research are offered.
\end{abstract}

Keywords: self-efficacy, instructional practice, reflective practice, tertiary education

\title{
Introduction
}

According to Richards (1987), two approaches have emerged concerning teacher education in second and foreign language teacher education programs. One approach considers education as 'training' and the other one is referred to as 'development' (Khezrlou, 2020a, 2020b). Traditionally, teachers were to observe and accurately imitate experienced teachers as role models to be followed in their own practice without doubting the underlying principles that governed practices performed in the classrooms. In such traditional training programs, as proposed by Richards (1987), the teacher is viewed as a technician who, according to Zeichner 
and Liston (1987), is "concerned primarily with the successful accomplishment of ends decided by others" (p. 27) who act as educators and experienced teacher trainers that offer help.

As Maftoon and Aghaalikhani (2018) assert, in teacher education programs based on development approach, which according to Richards (1987) is concerned with second and foreign language teacher education programs, teachers are explorers of their own classrooms, that is, they identify what dimensions of the classroom they want to know more about. The teachers are responsible to identify priorities for observation, analysis, and intervention, if necessary (Benson, 2001). Teachers are expected to learn new things about their abilities by thinking as well as their actions in educational contexts. This dynamic reflection on self-teaching would enable teachers to improve their instructional practice. This teacher reflection may also impact their self-efficacy beliefs. These concepts, however, have received less attention altogether and warrant further research. The present study was an attempt to shed light on these gaps in the literature.

\section{Review of the Literature}

\section{Teacher Efficacy}

Self-efficacy has been described by Bandura (1997) as the "beliefs in one's capabilities to organize and execute the courses of action required to produce given attainments" (p. 3). According to Bandura (2004), "self-efficacy beliefs are rooted in the core belief that one has the

power to effect changes by one's actions" (p. 622). Importantly, self-efficacy beliefs are 
“instrumental in defining one's experience ... and provide an avenue through which individuals exercise control over their own lives" (Pajares, 1992, p. 544). When teachers become reflective practitioners, "they move beyond a knowledge base of discrete skills to a stage where they integrate and modify skills to fit specific contexts" and eventually where skills are internalized and used for new strategies, thus developing a sense of self-efficacy (Larrivee, 2000, p. 294).

Teacher efficacy is defined as teachers' belief in their ability to influence the learning of students, even those who could be regarded as difficult or unmotivated (Guskey \& Passaro, 1994). Gibson and Dembo (1984) identified two dimensions of teacher efficacy: internal efficacy (or personal teaching) and external efficacy (or general teaching). Internal efficacy represented teachers' belief in their skills and abilities to overcome difficulties students may have in their learning. On the other hand, external efficacy represented the belief that any teacher's skills and abilities to promote student learning were less powerful than external factors such as socioeconomic status, family background, and parental influence.

Figure 1 that is adopted from Bandura (1997) depicts the multi-faceted nature of efficacy as including performance experience, observational learning, verbal persuasion, and emotional arousal. 


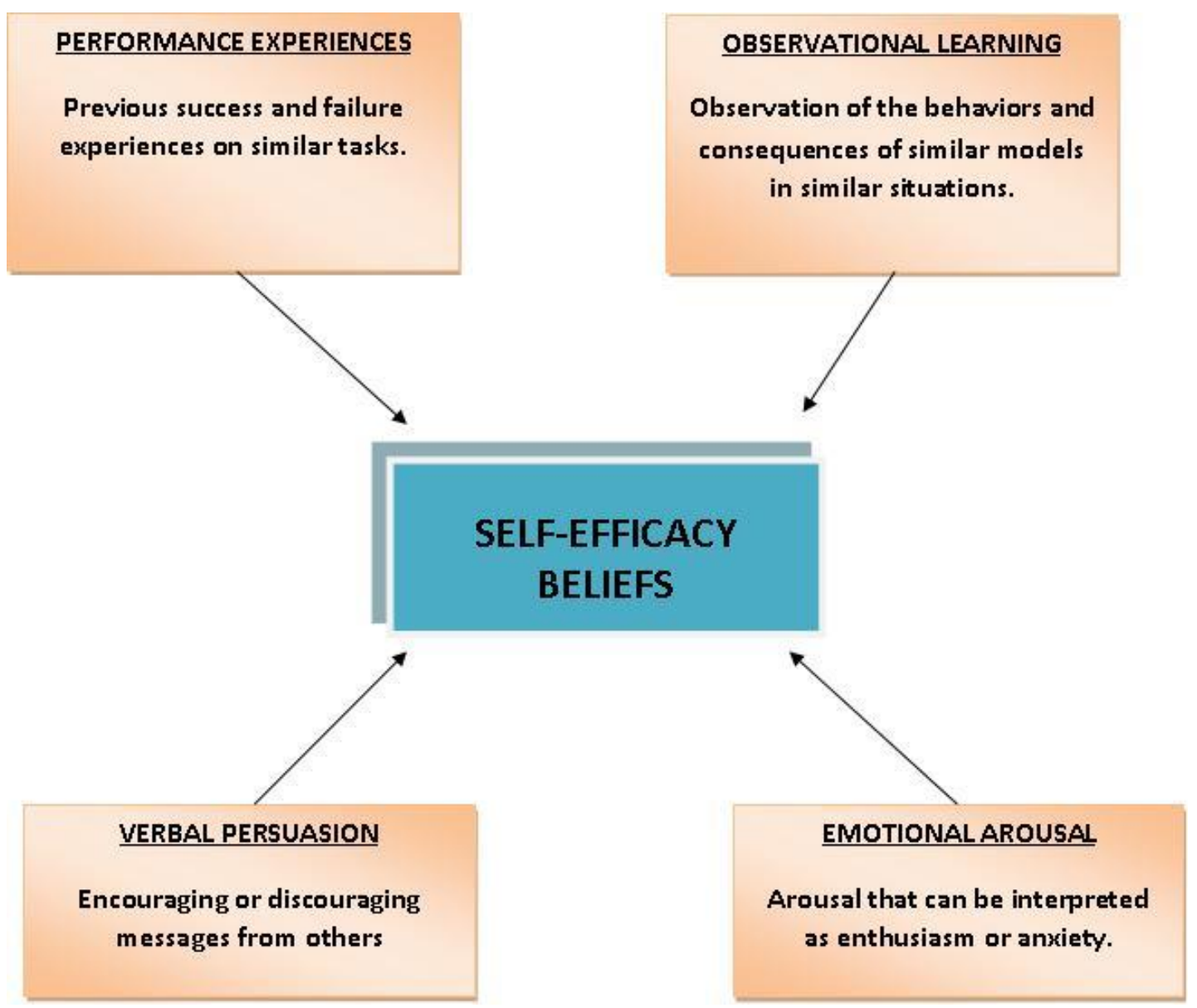

Figure 1. Self-efficacy model (Bandura, 1997)

Teacher efficacy was included in the current research because literature has suggested that the requirement to implement an innovation could affect teacher efficacy. Even if changes were made for the better, teachers could be uncomfortable with them and find them stressful (Harste, Leland, Schmidt, Vasquez, \& Ociepka, 2002; Tschannen-Moran, Woolfolk-Hoy \& Hoy, 1998). 
Therefore, the implementation of change initially has a negative impact on teachers' internal efficacy (Kruger, Davies, Eckersley, Newell, \& Cherednichenko, 2009; Ross 1994; Stein \& Wang, 1988). However, Ross (1994) and Stein and Wang (1988) argued that teachers' internal efficacy increased as they developed new strategies to cope with the change and witnessed evidence of improved student learning. Teacher efficacy was also reported to be associated with teachers' instructional behavior. For example, Tschannen-Moran, et al (1998) suggested that teachers' efficacy was positively related to their willingness to implement innovation and experiment with new teaching strategies as well as their investment of effort in teaching.

\section{Reflective Practice}

Teacher reflection has been argued to be the most worthwhile and sophisticated psychological concept in teacher education (Pajares, 1992; Pintrich \& Schrauben, 1992). However, there is no consensus about an explicit description of teachers' reflection (Skott, 2015), since other expressions are also applied that refer to the related concepts such as teachers' principles of practice, personal epistemologies, perspectives, and practical knowledge (Kagan, 1992). According to Levin (2015), these reflections underscore the ways teachers' co-existing beliefs grow out of distinct phases of the language teaching process.

Loughran (2002) underscored the necessity of giving explicit attention to the teachers' learning of how to reflect on their instructional practices, and he claimed that "simply being encouraged to reflect is likely to be as meaningful as a lecture on cooperative group work" (p. 33). Because reflective thinking is considered as not only an individual but also a social process (Khezrlou, 2012a, 2012b; Nelson \& Sadler, 2013), teacher educators need to set up an

environment where teachers feel secure in sharing their teaching practicum experiences with and 
obtaining feedback from their mentors and colleagues. As Figure 2 depicts, the conception teacher reflection is a complicated notion comprising many layers and components. Therefore, there are other contextual factors that play roles in the development of reflective thinking, such as feedback, and collaboration with others (Korthagen et al., 2001; Rogers, 2001). It seems that reflective thinking takes place in reaction to such experience if the other conditions are desirable for reflective thinking (Nelson \& Sadler, 2013). Experiences for teacher's reflective thinking may evidently rest in their observations and pedagogies in the actual classroom contexts (Gelfuso \& Dennis, 2014).

When applied to the teaching profession, teachers' subject-related reflections and assumptions are in reality the reflection of their individual epistemologies, which both represent their attentiveness to the notion of teaching and learning and include their perspectives towards their own unique and idiosyncratic as well as their prospects of both the curriculum and their learners (Skott, 2015).

Since the presentation of the concept of teacher reflection in the realm of second and foreign language instruction two decades ago, there have been quick developments in its research and the findings (Borg, 2015). Several research studies were conducted both in Iran and other countries which have attempted to illuminate the teachers' complicated inner lives lying behind their practice (Kubanyiova, 2015). 
The studies carried out in countries other than Iran on L2 teachers' reflection has been mainly concerned with the general teaching until recently. For the most part, the suggestion is that any subject matter is learned in a collective way and is not divided into specific curriculum areas. As an example, Oettingen (1995) led a cross-sectional study in order to make comparisons between individuals' reflections from different cultural backgrounds and thereby differences (in Germany, Moscow, and Los Angeles), with regard to individualism/collectivism, power distance, uncertainty avoidance and masculinity/femininity. The findings indicated that the individuals' teaching reflections differed across these cultures. Oettingen (1995) emphasized the prominent and undeniable role of culture in the process of a person's self-appraisal, entailing the adoptions, evaluations, and combination of information from different sources.

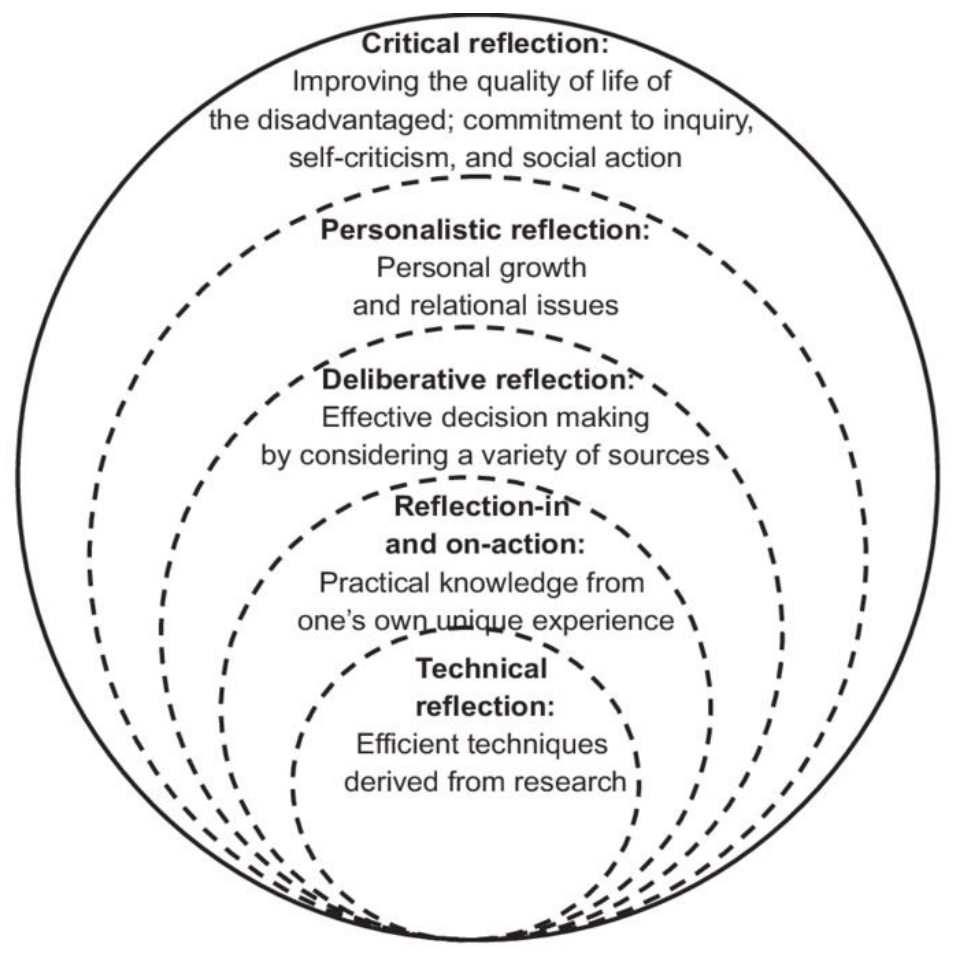

Figure 2. Teacher reflection components 
In another study, Yung (2002) highlighted the relationship between teachers' subjectoriented reflections about the entire matter of turning into a teacher, and their learning and measurement practices with regard to four aspects: 1) teachers' reflections about their stance with regard to facilitating the students' learning; 2) students' responsibilities for their own learning; 3) the specificities of the teacher-learner relationship; and 4) the way that the teacherlearner interaction needs to be carried out in the classroom from a meaning-centered approach to teaching and practice.

Likewise, He, Levin and $\mathrm{Li}$ (2011) underlined the impact of cultural environments on teachers' teaching assumptions by conducting a comparison between the subject matter and the basis of the instructional practices of one-hundred and six pre-service teachers from the Chinese and American contexts. The results clearly demonstrated that the cultural contexts could in fact play a noteworthy role with regard to the social prospects of teachers' responsibilities and their activities in the classroom. For example, whereas in the Chinese context, teachers are viewed as instances of authoritative individuals in the classroom, in the United States, teachers attempted to set up a friendly interaction and relationship with their learners. These different roles taken on by the different teachers in the different contexts give shape to their teaching evaluations without any doubt (He, Levin, \& Li, 2011).

In addition, teachers' subject-related reflection comprising both individual and teaching factors can be influenced by some issues (Fives \& Buehl, 2012). For example, the attitudes that a teacher has towards a learners may be suggestive of the parent-children relationship in the teacher's own family environment as well as the fact that the teachers' teaching styles and strategies might be the ones that his/her own teachers had implemented in the past. These likely matters can inevitably bring about teachers' particular reflections about their teaching such as the 
choice of conventional as opposed to innovative teaching methods and these specific factors have an eminent role to play in the teachers' classroom teaching process (Fives \& Buehl, 2012). Teachers' subject-related assumptions, consequently, function as a descriptive principle for their use of the pedagogical approaches and the implementation of the activities and tasks in the classroom (Skott, 2015).

Empirical research on language teachers' reflections about specific syllabus areas such as the linguistic issues taking into account grammar (Sanchez \& Borg, 2014), reading (Vaish, 2012), writing (Gilliland, 2015), listening (Graham, Santos, \& Francis-Brophy, 2014), pronunciation (Baker, 2014; Buss, 2015), speaking (Baleghizadeh \& Nasrollahi Shahri, 2014), and vocabulary (Macalister, 2012) have been witnessing great improvements and attracting a growing number of research studies. One can note the study by Graus and Coppen (2016) which was performed with the purpose of gaining insights about the teachers' reflections about grammar teaching at Dutch universities. The investigations found that teachers were more prone to the employment of explicit and intentional and deductive instruction procedures and were more enthusiastic to resort to a form-focused instruction. On the other hand, final-year undergraduates and postgraduates' results indicated that there was a different pattern such that a meaning-oriented, implicit instruction was obviously opted for and there was a motivation to foster a focus on form approach.

\section{Instructional Practice}

With a large number of talented learners being trained in the classrooms, a focus on proper and successful teaching practices that move away from the traditional instructional approaches used in the past is of essence (Torrance \& Sisk, 2001). The instructional practices signify the teachers' 
use of particular teaching approaches and activities in the classroom which in fact provide a true image of their perspective towards language learning and the ways to improve it (Torrance \& Sisk, 2001).

One of the key instructional differences between recent meaning-based and other approaches to the teaching process is the role of the teacher in the classroom. In a meaning-based classroom, teachers' role as Breen and Candlin (1980) argue, is to "facilitate communication process between all participants in the classroom, and between these participants and the various activities and the texts" (p. 99). They also state that teacher's role "is to act as an independent participant within the learning-teaching group" (p. 99). In addition, Breen and Candlin (1980) refer to some fundamental roles of the teacher in classroom and they include: initially is to help the communication practice between all the learners in the classroom, and between these learners and a number of different activities and texts. Secondly, it is to perform as "an independent participant within the learning-teaching" process. Thirdly, the role is that of "a researcher and learner, with much to contribute in terms of appropriate knowledge and abilities, actual and observed experience of the nature of learning and organizational capacities" (p. 99). In reaction to open-ended question about the role that the teacher plays in the classroom, the findings of AlMekhlafi and Ramani's (2011) study pinpoint the fact that almost all the participants referred to the teacher as a facilitator, enabling learners to take responsibility for their own learning, and be able to select appropriate strategies for their learning.

The traditional role of the teachers and students in the classroom has changed. Allwright (1984) argues that, in recent meaning-based classrooms, teachers cannot be perceived just as teachers and learners simply as learners any more, considering that they both are managers of learning. He goes on to add that the common view of the teacher as the dominating authority in 
the classroom is dissolved into a role that demands facilitating the communicative development in the class where learners feel secure, unthreatened and non-defensive. The role of the teachers in the traditional approach is essentially authoritative, while the role of helper and facilitator in meaning-based classrooms is different from the role of, in effect, omniscient disseminator of knowledge in the traditional approach (Holliday, 1994). Holliday (1994) noted that "mastery of various techniques in group work organization, error correction, student monitoring etc. which comes with the communicative package is not sufficient to provide a consolidated teacher status" (p. 176). That is, teachers' status and authority could he threatened by using meaning-based classrooms.

Teachers and administrators concurred on six main competencies that teachers need to develop. These include the advancement of thinking skills, the development of creative problem solving approaches, use of suitable approaches and materials, ease of autonomous research, and knowledge of affective needs (Nelson \& Prindle, 1992; Sadeghi, Khezrlou, \& Modirkhameneh, 2017). The literature includes not only cognitive but also interpersonal and intrapersonal fields as important competences that learners are expected to acquire.

Consequently, it does not seem unexpected that learners realize that their cognitive and affective needs are not being met in general education classrooms (Gentry, Rizza, \& Gable, 2001). Studies by Archambault et al. (1993) and Westberg, Archambault, Dobyns, and Slavin (1993) also highlighted the scarcity of appropriate challenging activities in the classrooms, particularly for low-level and gifted learners. The study by Vaughn, Schumm, and Kouzekanani (1993) found that the learners with distinct levels of skills preferred teachers who made changes in their teaching strategies in order to better take into account and accommodate their needs in the learning process. In addition, average- and high-achieving learners were enthusiastic to be 
challenged in the classroom and clearly preferred the teachers who offered instructional and curricular modifications commensurate with their capabilities. Therefore, for both normal and gifted learners to perform at optimal levels, the instructional context needs to present challenging opportunities that offer conditions for learners to solve problems and be creative and imaginative, while also calling for high standards of excellence (Feldhusen, VanTassel-Baska, \& Seeley, 1989).

Sowa and May (1997) also drew attention to the significance role of attempting to reinforce the intrapersonal skills by arguing that a stronger sense of individual identity can undeniably bring about confidence in an individual's cognitive appraisal and equips that person to effectively grapple with challenges from peers, school, and family.

In sum, the review of the literature on instructional practice makes it clear that effective teaching enquires of teachers to know their students as learners because it is "virtually impossible to make content relevant for learners whom you don't know" (Littky, 2004, as cited in Tomlinson, 2008, p. 27). Teachers should therefore determine and respond to individual students' learning needs, interest and learning preferences, which is likely to result in the needs of all learners in diverse classes being met.

\section{This Study}

It is presumed that teachers with a strong sense of self-efficacy are more self-reflective assuming that reflection would not only uncover weak dimensions of their teaching, but also would lead to the understanding or approval of strong points (Runhaar, Sanders \& Yang, 2010). On the contrary, teachers with a relatively weak level of self-efficacy are more likely to believe that 
reflection would make them expose more weak points than strong points, thereby leading them to avoid self-reflection. Besides, teachers with a high level of self-efficacy anticipate that, with effort, they can overcome failure and improve themselves and therefore the discovery of weak points would not essentially have a negative influence on their teaching and behavior. It is then sensible to expect that the stronger teachers' self-efficacy, the more they are inclined towards taking the risk of facing the disconfirming information through reflection (Runhaar, Sanders \& Yang, 2010).

Although there have been several studies investigating the role of self-efficacy, reflective teaching and instructional practice in the literature, there has not been any research intending to examine these variables in a single study. Therefore, the present study attempted to bridge this gap by examining these issues among tertiary education teachers in Iran. More specifically, this study attempted to address the following research questions:

RQ1.What is the relation between self-efficacy and instructional practice?

RQ2.What is the relation between self-efficacy and reflective practice?

\section{Method}

\section{Participants}

A total of 70 university teachers from both public and private universities in Iran participated in this study. There were 37 males and 33 females with their ages varying from 27 to 64 ( $M=$ $40.25, \mathrm{SD}=7.61)$. Convenience sampling was used in this study based on the availability of the teachers. Teachers' teaching experience and education background were controlled by taking 
into account only teachers with more than 10 years of experience $(\mathrm{M}=22.54,6.94)$ and those who mostly held $\mathrm{PhD}$ degrees $(\mathrm{N}=58)$ with some having MA $(\mathrm{N}=12)$. However, the marital status of the teachers was not controlled.

\section{Instruments}

\section{Teacher Efficacy Scale (TES)}

The Teacher Efficacy Scale (TES) (Gibson \& Dembo, 1984) was used in this study investigate the teachers' general and personal self-efficacy. This questionnaire is a commonly implemented survey in the area of teacher development. This questionnaire includes 16 items The TES was measured on a six-point Likert-type scale from strongly disagree (1) to strongly agree (6). This questionnaire was subject to reliability analysis through Cronbach's alpha. The results indicated a satisfactory value $(\alpha=.69)$.

\section{Instructional Practices Survey}

The Instructional Practices Survey is a Likert-scale questionnaire that is developed by Hong, Greene and Higgins (2006) with the aim of measuring teachers' instructional practices. The survey entails the pedagogical activities that would be helpful in developing the crucial skills in the cognitive, interpersonal, and intrapersonal areas. The whole questionnaire entailed 30 items on a Likert scale, with 1 indicating rarely and 4 almost always. The reliability of the questionnaire have been estimated through Cronbach's alpha $(\alpha=.89)$. 


\section{Teacher Reflection Questionnaire}

A 29-item questionnaire with a Likert scale ranging from $1=$ never to $5=$ always (Akbari, Behzadpoor \& Dadvand, 2010) was used in this study to evaluate teachers' reflective practice. The survey involved five distinct categories consisting of: Practical, Cognitive, Learner, MetaCognitive and Critical. Akbari et al. (2010) validated the whole questionnaire with 300 teachers through the use of the exploratory and confirmatory factor analyses. The validation process resulted in the lessening of the original 42 items into 29. The Cronbach's alpha for this survey was .92 .

\section{Procedure}

Teachers were first asked to complete written consent forms which provided them with information about the purpose of the study and their rights. Later, they were given the efficacy, instructional practice and reflection questionnaires to either complete on the research site or complete it at home and return it to the researcher via email. It took them no more than 45 minutes to complete the questionnaires.

\section{Results}

The scores from the questionnaires were calculated and analyzed using the statistical package for the social sciences (SPSS) software. Initially, the normality of the data was analyzed through the Kolmogorov-Smirnov test. A non-significant result $(\mathrm{p}>0.05)$ as is observed in Table 1 indicates normality for the obtained data. Subsequently, in order to provide answers to the research questions, a number of Pearson correlation coefficients were performed. For all analyses, a significance level of .05 was set. Effects sizes were interpreted based on Cohen (1988): $\eta p 2$ 
values of $.01, .06$, and .14 and $d$ values of $.20, .50$, and .80 were considered small, medium, and large.

Table 1.

One-Sample Kolmogorov-Smirnov Test Results

\begin{tabular}{|c|c|c|c|c|}
\hline & & efficacy & practice & reflection \\
\hline $\mathrm{N}$ & & 70 & 70 & 70 \\
\hline \multirow[t]{2}{*}{ Normal Parameters ${ }^{\mathrm{a}, \mathrm{b}}$} & Mean & 71.1143 & 34.2000 & 90.4571 \\
\hline & Std. Deviation & 7.95193 & 6.76221 & 16.24958 \\
\hline \multirow[t]{3}{*}{ Most Extreme Differences } & Absolute & .076 & .105 & .077 \\
\hline & Positive & .076 & .087 & .077 \\
\hline & Negative & -.076 & -.105 & -.076 \\
\hline Kolmogorov-Smirnov Z & & .638 & .878 & .643 \\
\hline Asymp. Sig. (2-tailed) & & .810 & .424 & .803 \\
\hline
\end{tabular}

a. Test distribution is Normal.

b. Calculated from data. 
In order to find out whether there was any relationship between the participants' self-efficacy and instructional practice, a Pearson correlation coefficient was performed. Results are presented in Tables 2 and 3.

Table 2.

Descriptive Statistics for Self-efficacy and Instructional Practice

\begin{tabular}{lccc}
\hline & Mean & Std. Deviation & N \\
\hline efficacy & 71.1143 & 7.95193 & 70 \\
practice & 34.2000 & 6.76221 & 70 \\
& & \\
\hline
\end{tabular}

According to Table 2, the mean of efficacy is 71.11 with a standard deviation of 7.95 and the mean for the instructional practice is 34.20 with an SD of 6.76 .

Table 3.

Pearson Correlation Results for Self-efficacy and Instructional Practice

\begin{tabular}{llcc}
\hline & & efficacy & practice \\
\hline efficacy & Pearson Correlation & 1 & $.461^{* *}$ \\
& Sig. (2-tailed) & & .000 \\
practice & $\mathrm{N}$ & 70 & 70 \\
& Pearson Correlation & $.461^{* *}$ & 1 \\
& Sig. (2-tailed) & .000 & 70 \\
\hline
\end{tabular}

**. Correlation is significant at the 0.01 level (2-tailed). 
The results of Table 3 indicate that there is a moderate, positive, and significant correlation $(\mathrm{r}=$ 0.46, $\mathrm{p}=0.000$ ) between the participants' self-efficacy perceptions and their instructional practice.

In order to provide an answer to the second research question which was concerned with the relationship between the teachers' self-efficacy and reflective practice, a Pearson correlation coefficient was run. Results are demonstrated in Tables 4 and 5.

Table 4.

Descriptive Statistics for Self-efficacy and Reflective Practice

\begin{tabular}{lccc}
\hline & Mean & Std. Deviation & N \\
\hline efficacy & 71.1143 & 7.95193 & 70 \\
reflection & 90.4571 & 16.24958 & 70 \\
\hline
\end{tabular}

Table 5.

Pearson Correlation Results for Self-efficacy and Reflective Practice

\begin{tabular}{llrr}
\hline & & efficacy & reflection \\
\hline efficacy & Pearson Correlation & 1 & $.276^{*}$ \\
& Sig. (2-tailed) & & .021 \\
reflection & $\mathrm{N}$ & 70 & 70 \\
& Pearson Correlation & $.276^{*}$ & 1 \\
& Sig. (2-tailed) & .021 & 70 \\
\hline
\end{tabular}

*. Correlation is significant at the 0.05 level (2-tailed). 
As the results of Table 5 display, there is a small, positive, and significant correlation $(\mathrm{r}=0.27, \mathrm{p}$ $=0.02$ ) between the teachers' self-efficacy perceptions and their reflective practice.

\section{Discussion}

The present study intended to explore the relationship between tertiary education teachers' selfefficacy perceptions and their instructional practice on the one hand and their self-efficacy and reflective practice on the other hand. The results of Pearson correlation analysis denoted a significant relationship between teachers' self-efficacy and their instructional practice. This finding lends credence to the findings of previous studies (e.g., Artino, 2012; Gibson \& Dembo, 1984; Guskey, 1988; Sadeghi \& Khezrlou, 2014, 2016; Woolfolk \& Hoy, 1990). Richards (2008) contends that teachers' efficacy perceptions is related and also enhances their classroom teaching practices. A large number of studies have signified relationships between teachers' self-efficacy beliefs and their teaching success (e.g., Bakker \& Bal, 2010). Rimm-Kaufman and Hamre (2010) recommend that assessing the ways that teachers' self-efficacy perceptions determine their routine methods of instruction would bear significant implications for their teaching quality enhancement. Rockoff, Jacob, Kane, and Staiger (2008) also underscored that self-efficacy beliefs are theoretically more consistent with teaching efficacy compared to the personality characteristics, which is due to the higher specificity and contextualization. In line with this, the current study was an investigation of the relationship between self-efficacy perceptions and instructional effectiveness, and conclusions are arrived at with respect to the role that selfefficacy has in teachers' teaching practice. 
The second research question aimed at understanding the teachers' self-efficacy perceptions and their reflective practices. The results showed that there was a significant and positive correlation between these two concepts - albeit with a small effect size. This significant finding bears out that of Braun and Crumpler (2004) who concluded that there was a positive relationship between reflectivity and efficacy. Braun and Crumpler postulate that reflectivity enables teachers to become more efficacious and believe in themselves. Inchausti (1991) presumes this as second self and Colton and Sparks-Langer (1993) consider it as an ongoing and recurrent endeavor to examine and make sense of oneself that is reciprocally linked to steadily and constantly serving others (Braun \& Crumpler, 2004). They argue that the second self would facilitate teachers' enhancement of their identity and enrichment of their efficacy beliefs, modification of their lives in a better way, cultivate their skills and capacities, and ultimately become included in reflective practice (Braun \& Crumpler, 2004).

In order for teachers to thrive in the teaching, they need the tools essential for dealing with challenges they face in the profession. Several scholars have put forth the recommendation that critical reflection is a crucial tool to help teachers deal with problems that take place in the classroom context (Dewey, 1933; Schon, 1987; Van Manen, 1977). As mentioned earlier, if teachers want to feel ensured in their skills and capacities to cope with and resolve challenges, then the probability is that they will be encouraged to keep on finding solutions. Teacher education programs robustly impact the degree to which novice teachers are able to reflect on their teaching and problem-solve.

There has been some rewarding research that recommends that teachers need to use critical reflection as a problem-solving tool if they are trained to think in that way (Dieker \& Monda-Amaya, 1997; Hatton \& Smith, 1995; Pultorak, 1996; SparksLanger, Simmons, Pasch, 
Colton, \& Starko, 1991; Yost, Sentner, \& Forlenza-Bailey, 2000; Zeichner \& Liston, 1987). Actually, a study has demonstrated that implementing critical reflection throughout the teacher education experience has led to a marked ability of first year teachers to reflect on critical levels (Yost, 1997; Yost ForlenzaBailey, \& Shaw, 1999). Goddard and Foster (2001) recommend that research is necessary to uncover how the failure to develop critical reflective skills could be suggestive of a teacher's preference to quit the teaching profession. The issue that reflection is cultivated when teachers are involved in research has been well attested in previous research (Feuyo \& Koorland, 1997; Lytle \& Cochran-Smith, 1992; Yost \& Forlenza-Bailey, 2000). When schools cooperate with universities in the induction process and teacher reflection is a preliminary emphasis, augmented teacher retention amounts have been demonstrated (Kelley, 2004; Wood, 2001).

\section{Conclusion}

Studies on successful teachers underscore the essence of praxis in teacher education, as well as an encouraging and caring school culture. The studies also indicate that self-efficacy and reflection are two essential elements associated with teacher retention, determination, and perseverance. These findings are attested by a review of the literature that refers to two factors accompanied with enhanced resiliency: gaining success and the capacity to solve problems (Bobeck, 2002). Concerning the significance of these issues, the present study, offers some insights into these factors and presents recommendations for teacher education programs as to how resiliency and persistence can be cultivated and augmented in teacher candidates. Teacher educators would benefit from observing teachers' classroom practices and training them how to alter their instruction for the better and then can monitor them regarding their use of this information (Allinder, 1994). Particular modifications in teaching practices might include several 
instructional choices to guide teachers in their use of these alternatives. Since the implementation of decision rules and diverse teaching choices impact learners' development and their learning outcomes, teachers' efficacy and use of interventions may enhance which is also supported by previous research demonstrating that teachers' beliefs can change when they understand the influence of new teaching practices (Florio-Ruane \& Lensmire, 1990; Guskey, 1988). Another suggestion is that educators can raise teachers' awareness about the advantages and value of exploring their assumptions, the interactions between their beliefs and actions, and the foundation for those beliefs. This type of introspection would then lead to alterations in teachers' belief systems, either concurrent with or prior to modifications in knowledge (Nespor, 1987). This elucidates the essence of efficacy for teachers and teacher educators. Teachers' efficacy and their respective beliefs are pertinent to the ways that teachers understand and think of their roles, perform instruction, and interact with learners (Khezrlou, 2019a, 2019b, 2019c; Khezrlou, Ellis \& Sadeghi, 2017).

In addition to these findings, we would also like to identify the limitations of this study. Firstly, this study had a cross-sectional design. It would be interesting to replicate this study by using a longitudinal design and applying diverse research methods. Secondly, all the variables were measured through self-reports, which probably results in method bias. Thus, future studies are encouraged to triangulate the data through the application of different instruments. Thirdly, the teachers were sampled from both public and private universities in Iran. It is believed that tertiary education settings and national educational policies could to some extent impact teachers' teaching practices. Hence, further research would benefit from examining teachers of different other institutions such as distance learning universities (Payam-e-Nour), private language institutes, and schools. Lastly, it would be interesting to put more emphasis on the concept of 
interdependency in subsequent studies to explore the role of situational factors in teachers' teaching practices and their self-perceptions.

\section{Authors' contributions}

All authors are responsible for all parts of the paper. The author(s) read and approved the final manuscript

\section{Funding}

No funding was available to the present study.

\section{Availability of data and materials}

The data will be available upon requesting.

\section{Competing interests}

The authors declare that they have no competing interests.

\section{References}

Akbari, R., Bhezadpoor, F. \& Dadvand, B. (2010). Development of English language teaching reflection inventory. System, 38, 211-227.

Allinder, R. M. (1994). The relationship between efficacy and the instructional practices of special education teachers and consultants. Teacher Education and Special Education, $17(2), 86-95$.

Allwright, R. (1984). The importance of interaction in classroom language learning. Applied Linguistics, 5, 156-171.

Al-Mekhlafi, Abdu M., \& Nagaratnam, Ramani P. (2011). Difficulties in teaching and learning grammar in an EFL context. International Journal of Instruction, 4(2), 1-19. 
Archambault, F., Westberg, K. L., Brown, S. W., Hallmark, B. W., Zhang, W., \& Emmons, C. L. (1993). Classroom practices used with gifted third and fourth grade students. Journal for the Education of the Gifted, 16, 103-119.

Artino, R. A. J. (2012). Academic self-efficacy: from educational theory to instructional practice. Perspect Med Educ, 1, 76-85.

Baker, A. A. (2014). Exploring teachers' knowledge of second language pronunciation techniques: Teacher cognitions, observed classroom practices, and student perceptions. TESOL Quarterly, 48(1), 136-163.

Bakker, A. B., \& Bal, M. P. (2010). Weekly work engagement and performance: A study among starting teachers. Journal of Occupational and Organizational Psychology, 83, 189-206.

Baleghizadeh, S., \& Nasrollahi Shahri, M. N. (2014). EFL teachers' conceptions of speaking competence in English. Teachers and Teaching, 20(6), 738-754.

Bandura, A. (1997). Self-efficacy: The exercise of control. New York: W. H. Freeman and Company.

Bandura, A. (2004). The growing primacy of perceived efficacy in human self-development, adaptation and change. In M. Salanova, R. Grau, I.M. Martinez, E. Cifre, S. Llorens \& M. García-Renedo (Eds.) Nuevos horizontes en la investigactión sobre autoeficacia (pp. 33-51) Castellón: Colección Psyique.

Benson, P. (2001). Teaching and researching autonomy in language learning. Harlow, Hong Kong: Longman. 
Bobeck, B.L. (2002). Teacher resiliency: A key to career longevity. The Clearing House, 5, 202205.

Borg, S. (2015). Teacher cognition and language education: Research and practice. London, UK: Bloomsbury.

Braun, J. A., \& Crumpler, T. P. (2004). The social memoir: An analysis of developing reflective ability in a pre-service methods course. Teaching and Teacher Education, 20, 59-75.

Breen, M. P., \& Candlin, C. N. (1980). The essentials of a communicative curriculum in language teaching. Applied Linguistics, 1(2), 89-112.

Buss, L. (2016). Beliefs and practices of Brazilian EFL teachers regarding pronunciation. Language Teaching Research, 20(5), 619-637.

Cohen, P. A. (1981). Student ratings of instruction and student achievement: A meta-analysis of multi-section validity studies. Review of Educational Research, 51, 281-309.

Dewey, J. (1933). How we think: A restatement of the relations of reflective thinking to the educative process (2nd revised edition). Boston: D.C. Heath.

Dieker, L.A., \& Monda-Amaya, L.E. (1997). Using problem-solving and effective teaching frameworks to promote reflective thinking in preservice special educators. Teacher Education and Special Education, 20(1), 22-36.

Feldhusen, J., VanTassel-Baska, J., \& Seeley, K. (1989). Excellence in educating the gifted. Denver, CO: Love. 
Fives, H., \& Buehl, M. M. (2012). Spring cleaning for the messy construct of teachers' beliefs: What are they? Which have been examined? What can they tell us? In K. R. Harris, S. Graham, \& T. Urdan (Eds.), APA Educational Psychology Handbook (Vol. 2, pp. 471499). Washington DC: APA.

Florio-Ruane, S., \& Lensmire, T. J. (1990). Transforming future teachers' ideas about writing instruction. Curriculum Studies, 22, 277-289.

Fueyo, V., \& Koorland, M.A. (1997). Teacher as researcher: A synonym for professionalism. Journal of Teacher Education, 48, 336-344.

Gelfuso, A., \& Dennis, D. V. (2014). Getting reflection off the page: The challenges of developing support structures for pre-service teacher reflection. Teaching and Teacher Education, 38, 1-11.

Gentry, M., Rizza, M. G., \& Gable, R. K. (2001). Gifted students' perceptions of their class activities: Differences among rural, urban, and suburban student attitudes. Gifted Child Quarterly, 45, 115-129.

Gibson, S., \& Dembo, M. (1984). Teacher efficacy: A construct validation. Journal of Educational Psychology, 76, 569-592.

Gilliland, B. (2015). High school teacher perspectives and practices: Second language writing and language development. Language and Education, 29(4), 287-301.

Goddard, J.T., \& Foster, R.Y. (2001). The experiences of neophyte teachers: A critical constructivist assessment. Teaching and Teacher Education, 17, 349-365. 
Graham, S., Santos, D., \& Francis-Brophy, E. (2014). Teacher beliefs about listening in a foreign language. Teaching and Teacher Education, 40, 44-60.

Graus, J., \& Coppen, P. (2016). Student teacher beliefs on grammar instruction. Language Teaching Research, 20(5), 1-29.

Guskey, T. R. (1988). Teacher efficacy, self-concept, and attitudes toward the implementation of instructional innovation. Teaching and Teacher Education, 4, 63-69.

Guskey, T. R., \& Passaro, P. D. (1994). Teacher efficacy: A study of construct dimensions. American Educational Research Journal, 31(3), 627-643.

Harste, J. C., Leland, C., Schmidt, K., Vasquez, V., \& Ociepka, A. (2004). Practice makes practice: Or does it? Reading On-Line, 4(1), 1-70.

Hatton, N., \& Smith, D. (1995). Reflection in teacher education: Towards definition and implementation. Teaching and Teacher Education, 11(1), 33-49

He, Y., Levin, B. B., \& Li, Y. (2011). Comparing the content and sources of the pedagogical beliefs of Chinese and American pre-service teachers. Journal of Education for Teaching, $37(2), 155-171$.

Holliday, A. R. (1994). Appropriate methodology and social context. Cambridge: Cambridge University Press.

Hong, E., Greene, M. T., \& Higgins, K. (2006). instructional practices of teachers in general education classrooms and gifted resource rooms: Development and validation of the instructional practice questionnaire. Gifted Child Quarterly, 50(2), 91-103. 
Inchausti, R. (1991). Ignorant perfection of ordinary people. SUNY Press, Albany.

Kagan, D. M. (1992). Professional growth among preservice and beginning teachers. Review of Educational Research, 62(2), 129-169.

Kelley, L.M. (2004). Why induction matters. Journal of Teacher Education, 55, 438-448.

Khezrlou, S. (2020a). Training planning in second language narrative writing. ELT Journal, 74(1), 49-62.

Khezrlou, S. (2020b). The role of task repetition with direct written corrective feedback in L2 writing complexity, accuracy and fluency. Journal of Second Language Studies, 3(1), 3154.

Khezrlou, S. (2019a). Effects of timing and availability of isolated FFI on learners' written accuracy and fluency through task repetition. The Language Learning Journal. Doi: $10.1080 / 09571736.2019 .1656765$

Khezrlou, S. (2019b). Task repetition and corrective feedback: The role of feedback types and structure saliency. English Teaching and Learning, 43(2), 213-233.

Khezrlou, S. (2019c). Form-focused instruction in CALL: What do learners think? RELC, 50(2), 235-251.

Khezrlou, S. (2012a). Cognitive strategy training: Improving reading comprehension in the language classroom. Journal of Teaching Language Skills, 3(4), 77-98.

Khezrlou, S. (2012b). The relationship between cognitive and metacognitive strategies, age and level of education. The Reading Matrix, 12(1), 50-61. 
Khezrlou, S., Ellis, R., \& Sadeghi, K. (2017). Effects of computer-assisted glosses on EFL learners' vocabulary acquisition and reading comprehension in three learning conditions. System, 65, 104-116.

Korthagen, F.A.J., Kessels, J., Koster, B., Lagerwerf, B., \& Wubbels, T. (2001). Linking practice and theory: The pedagogy of realistic teacher education (pp. 109-128). New Jersey, USA: Lawrence Erlbaum Associates.

Kubanyiova, M. (2015). The role of teachers' future self-guides in creating L2 development opportunities in teacher - led classroom discourse: Reclaiming the relevance of language teacher cognition. The Modern Language Journal, 99(3), 565-584.

Kruger, T., Davies, A., Eckersley. B., Newell, F., \& Cherednichenko, B. (2009). An inquiry kit for university-school partnerships. Canberra, Australia: Teaching Australia.

Larrivee, B. (2000): Transforming Teaching Practice: Becoming the critically reflective teacher. Reflective Practice: International and Multidisciplinary Perspectives, 1(3), 293-307.

Levin, B. B. (2015). The development of teachers' beliefs. In H. Fives \& M. G. Gill (Eds.), International handbook of research on teachers' beliefs (pp. 48-65). New York, NY: Routledge.

Loughran, J. J. (2002). Effective reflective practice: In search of meaning in learning about teaching. Journal of Teacher Education, 53(1), 33-43.

Lytle, S.L., \& Cochran-Smith, M. (1992). Teacher research as a way of knowing. Harvard Educational Review, 62, 447-473. 
Macalister, J. (2012). Pre-service teacher cognition and vocabulary teaching. RELC Journal, 43(1), 99-111.

Maftoon, P; \& Aghaalikhani, H. (2018). English Teacher Education Programs and Professionalism: The case of Iranian Novice/Experienced Teachers. Research in English Language Pedagogy, 6, 78-94.

Nelson, F. A., \& Sadler, T. (2013). A third space for reflection by teacher educators: a heuristic for understanding orientations to and components of reflection. Reflective Practice, 14(1), 43-57.

Nespor, J. (1987). The role of beliefs in the practice of teaching. Curriculum Studies, 19, $317-$ 328.

Oettingen, G. (1995). Cross-cultural perspectives on self-efficacy. In A. Bandura (Ed.), Selfefficacy in changing societies (pp. 149-176). Cambridge, United Kingdom: Cambridge University Press.

Pajares, M. F. (1992). Teachers' beliefs and educational research: Cleaning up a messy construct. Review of Educational Research, 62(3), 307-332.

Pintrich, P. R., \& Schrauben, B. (1992). Students' motivational beliefs and their cognitive engagement in classroom academic tasks. In D. H. Schunk \& J. L. Meece (Eds.), Student perceptions in the classroom (pp. 149-183). Hillsdale, NJ: Lawrence Erlbaum.

Richards, J. C. (1987). The teacher training dilemma. TESOL Quarterly, 21(2), 56-70. 
Rimm-Kaumfan, S. E., \& Hamre, B. K. (2010). The role of psychological and developmental science in efforts to improve teacher quality. Teachers College Record, 112, 2988-3023.

Rockoff, J. E., Jacob, B. R., Kane, T., \& Staiger, D. O. (2008). Can you recognize an effective teacher when you recruit one? (Working Paper No. 14485). Retrieved

Ross, J. A. (1994). Teacher efficacy and the effect of coaching on student achievement. Canadian Journal of Education, 17(1), 51-65.

Runhaar, P., Sanders, K., \& Yang, H. (2010). Stimulating teachers' reflection and feedback asking: An interplay of self-efficacy, learning goal orientation, and transformational leadership. Teaching and Teacher Education, 26, 1154-1161.

Sadeghi, K., \& Khezrlou, S. (2014). Burnout among English language teachers in Iran: Do sociodemographic characteristics matter? Procedia- Social and Behavioural Sciences, 98, 1590-1598.

Sadeghi, K., \& Khezrlou, S. (2016). The experience of burnout among English language teachers in Iran: Self and other determinants. Teacher Development, 20(5), 1-17.

Sadeghi, K., Khezrlou, S., \& Modirkhameneh, S. (2017). CALLing Iranian learners of L2 English: Effect of gloss type on lexical retention and academic reading performance under different learning conditions. Journal of Research in Reading, 40(1), 66-86.

Sanchez, H. S., \& Borg, S. (2014). Insights into L2 teachers’ pedagogical content knowledge: A cognitive perspective on their grammar explanations. System, 44, 45-53.

Schon, D.A. (1997). Educating the reflective practitioner. San Francisco: Jossey-Bass. 
Skott, J. (2015). The promises, problems, and prospects of research on teachers' beliefs. In H. Fives, \& M. G. Gill (Eds.), International hand book of research on teachers' beliefs (pp. 13-30). New York: Routledge

Sowa, C., \& May, K. (1997). Expanding Lazarus and Folkman's paradigm to the social and emotional adjustment of gifted children and adolescents (SEAM). Gifted Child Quarterly, $41,36-42$.

Sparks-Langer, G., Simmons, J. M, Pasch, M., Colton, A., \& Starko, A. (1991). Reflective pedagogical thinking: How can we promote it and measure it? Journal of Teacher Education, 45, 310-318.

Stein, M., \& Wang, M. (1988). Teacher development and school improvement: The process of teacher change. Teaching and Teacher Education, 4(2), 171-187.

Tomlinson, B. (2008). Language acquisition and language learning materials. In B. Tomlinson (ed.), English language teaching materials (pp. 184-197). London: Continuum.

Torrance, E. P., \& Sisk, D. A. (2001). Gifted and talented children in the regular classroom. Buffalo, NY: Creative Education Foundation Press.

Tschannen-Moran, M., Woolfolk-Hoy, A., \& Hoy, W. K. (1998). Teacher efficacy: Its meaning and measure. Review of Educational Research, 68(2), 202-248.

Vaish, V. (2012). Teacher beliefs regarding bilingualism in an English medium reading program. International Journal of Bilingual Education and Bilingualism, 15(1), 53-69. 
Van Manen, J. (1977). Linking ways of knowing with ways of being practical. Curriculum Inquiry, 6, 205-208.

Vaughn, S., Schumm, J. S., \& Kouzekanani, K. (1993). What do students with learning disabilities think when their general education teachers make adaptations? Journal of Learning Disabilities, 26, 545-555.

Westberg, K. L., Archambault, F. X., Dobyns, S. M., \& Slavin, T. J. (1993). The classroom practices observation study. Journal for the Education of the Gifted, 16, 120-146.

Wood, A. L. (2001). What does research say about teacher induction and IHE/LEA collaborative programs? Issues in Teacher Education, 10(2), 69-81.

Woolfolk, A. E., \& Hoy, W. K. (1990). Prospective teachers' sense of efficacy and beliefs about control. Journal of Educational Psychology, 8, 812-91.

Yost, D.S. (1997). The moral dimensions of teaching and preservice teachers: Can moral dispositions be influenced? Journal of Teacher Education, 48, 281-192.

Yost, D.S., \& Forlenza-Bailey, A.M. (2000). The Impact of a fifth year program on the leadership abilities of beginning teachers. The Professional Educator, 23(1), 35-47.

Yost, D.S., Forlenza-Bailey, A., \& Shaw, S.F. (1999). Teachers who embrace diversity: The role of reflection, discourse, and field experiences in education. The Professional Educator, 21(2), 1-14. 
Yost, D.S., Sentner, S.M., \& Forlenza-Bailey, A. (2000). An examination of the construct of critical reflection: Implications for teacher education programming in the 21 st century. Journal of Teacher Education, 51, 39-49.

Yung, B. H.-W. (2002). Same assessment, different practice: Professional consciousness as a determinant of teachers' practice in a school-based assessment scheme. Assessment in Education: Principles, Policy \& Practice, 9(1), 97-117.

Zeichner, K.M., \& Liston, D. P. (1987). Teaching student teachers to reflect. Harvard Educational Review, 56(1), 23-48. 


\section{Figures}

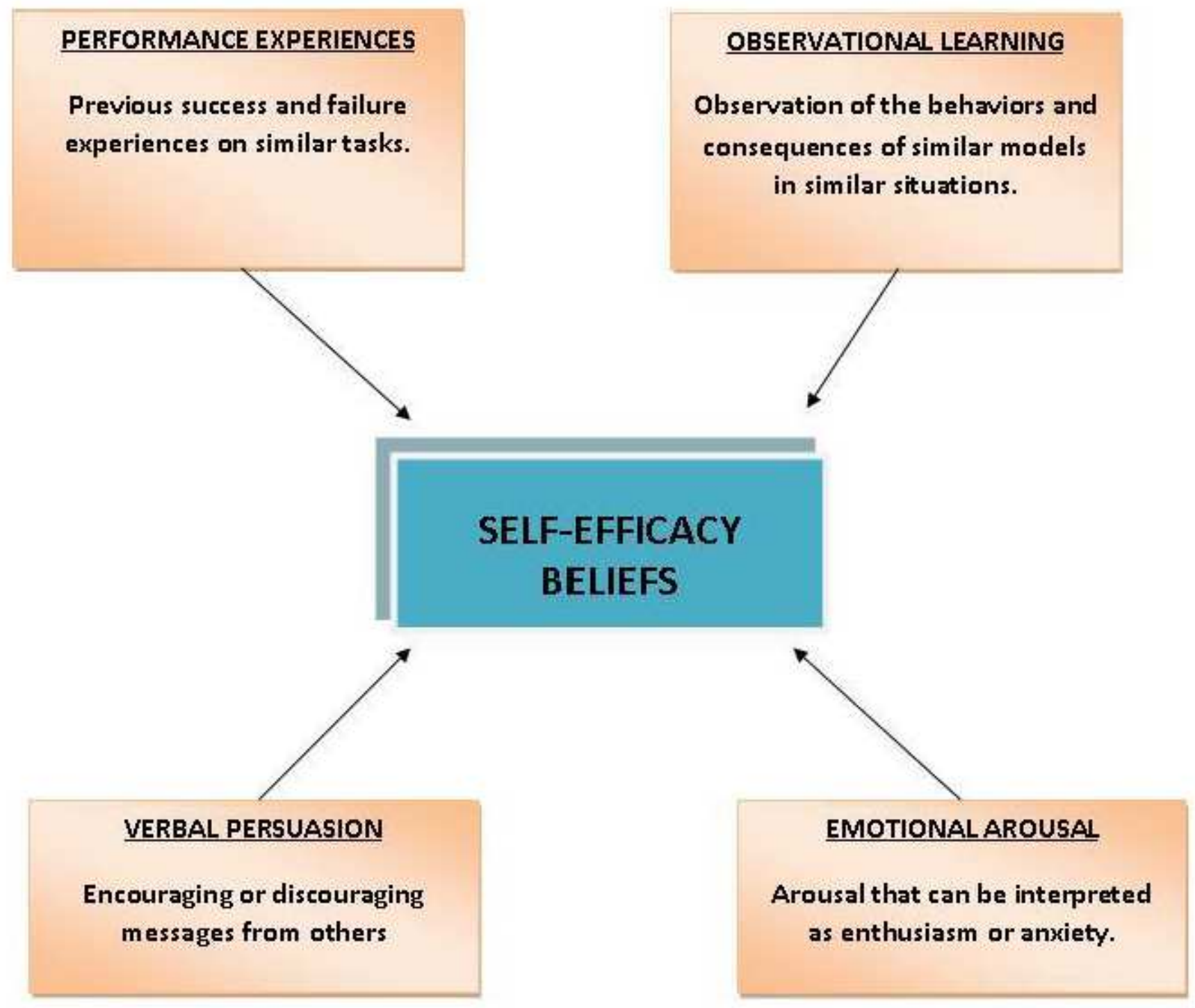

Figure 1

Self-efficacy model (Bandura, 1997) 


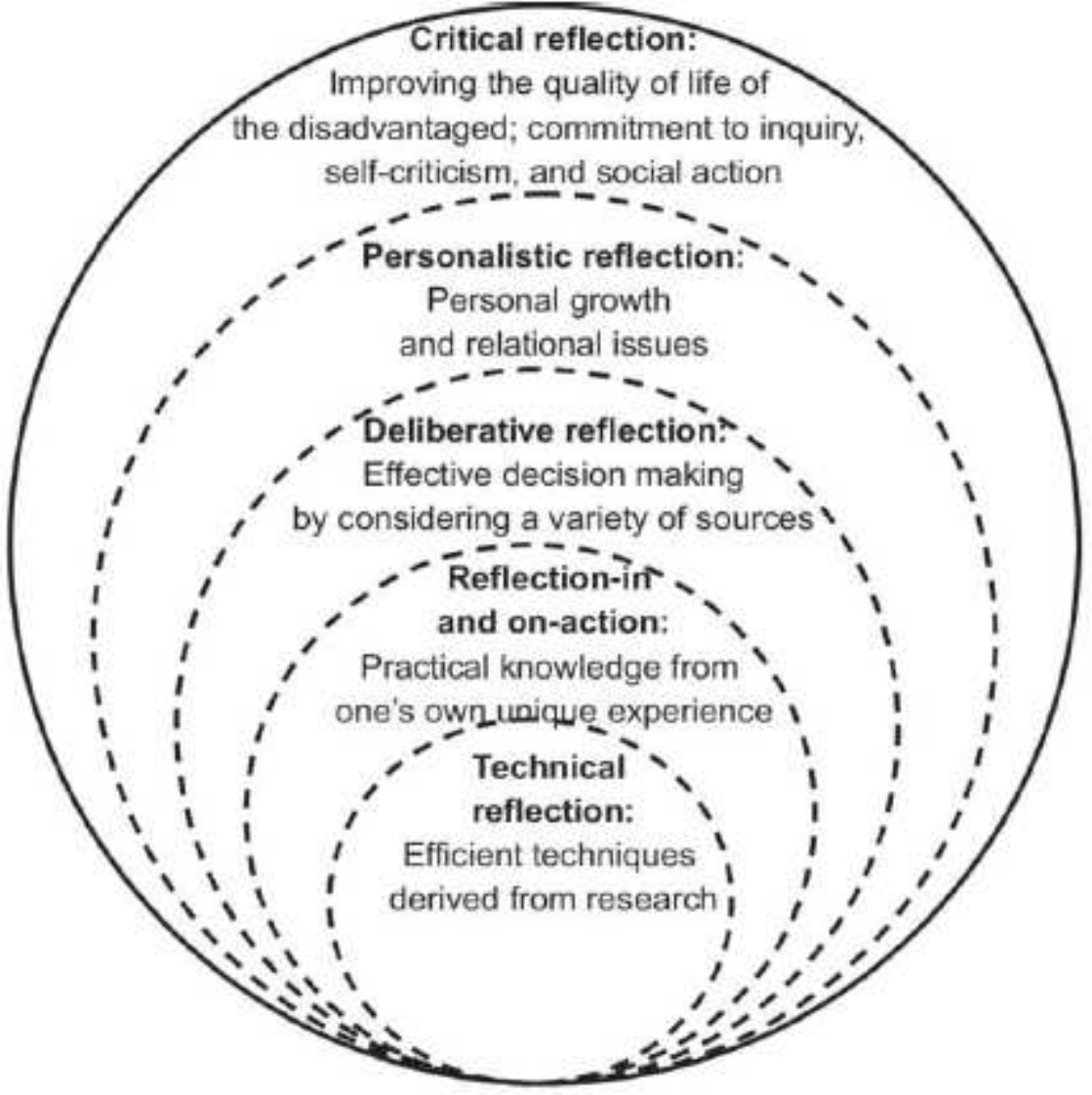

Figure 2

Teacher reflection components 